\title{
ONGOING DISCUSSION REGARDING THE CORRELATION BETWEEN EXPROPRIATION AND SALES
}

\begin{abstract}
Purpose. The purpose of the article is ongoing discussion regarding the correlation between expropriation (namely - the purchase of private property objects for public use) and sales, expanding the arguments in favor of inexpediency of their identification and further determining the need to abandon the use of civil agreements in the expropriation procedure. Methods. The research methodology consists of general and special methods of scientific cognition, including historical and legal, comparative and legal, systematic and structural methods, deduction, induction, analysis, synthesis, etc.

Results. The author, in the first part of the article, briefly studies the main arguments of scholars, which were put forward in the pre-revolutionary period to support and criticize the idea of defining expropriation as forced sales. The author formulates the preconditions for the use of civil agreements in the expropriation procedure and comes to the conclusion that there were no necessary conditions for settling redemption issues for public needs without private law instruments in pre-revolutionary times.

In the second part of the article, the author lists the main differences between the relations of expropriation and sales, which are covered in the modern Ukrainian scientific literature, and supplements it with the own analysis of the differences between them.

Conclusions. The analysis carried out in the article demonstrates that the relationships of redemption for public needs are not relationships of sales, and cannot be recognized as civil ones on the grounds that the expropriation procedure involves the conclusion of the purchase and sale agreement. The author pays attention to the fact that legal instruments that logically mediate the civil relations of sales - are not intended and should not be used in atypical situations. The author offers to consider the possibility of introducing a new instrument for Ukraine - an expropriation agreement - into legal circulation, which can correct the shortcomings of the current legislation.
\end{abstract}

Key words: expropriation, redemption for public needs, alienation of private property objects for public needs or for reasons of public necessity, sales, contract of redemption for public needs, purchase and sale agreement, expropriation agreement, correlation, differences, legal nature. 
Anastasiia Antonenko, PhD Student at the Department of Administrative Law and Process of the Institute of Law of Taras Shevchenko National University of Kyiv orcid.org/0000-0003-2421-7768 AntonenkoA@mail.univ.kiev.ua

\section{Introduction}

The continuous development of public relations, including international cooperation, necessitates the continuous improvement of normative and legal regulation in the country, based on the needs of society, international treaties, requirements and obligations assumed by Ukraine, tasks, objectives and guidelines approved in official documents, as well as scientific developments, which substantiate the most effective ways to optimize public policy, public administration and regulatory base. One of the important tasks, under such circumstances, is to revise outdated legal structures, which due to the historical peculiarities of the formation of national state and law are still used, but contradict modern jurisprudence, current legislation, experience and practice of leading European states. In this perspective, it is worth paying attention to the legal institution of alienation of private property objects for public needs or for the reasons of public necessity (hereinafter - expropriation), which was developed intermittently in Ukraine and, despite ancient history, was not developed at the same level as and in European countries. In particular, private and legal instruments are still used during the expropriation in Ukraine, as it was in the pre-revolutionary times in terms of no developed science of administrative law. The issue of the legal nature of the institution of expropriation due to that fact still provokes discussions among scholars, who do not want to finally abandon the concepts that dominated in the XIX century.

Occasionally we would like to recall that identification of legal phenomena of sales and expropriation, which was also called forced sale on this basis, was typical for the legal science of the pre-revolutionary period due to the fact of concluding a purchase and sale agreement during the expropriation (Venetsianov, 1891). This resulted in the recognition of its private and legal nature even when there was no other procedure than forced alienation, the issue of which was settled only in an imperative manner, and the will of the property owner did not have any sense (Venetsianov, 1891).

The confidence of the supporters of the private and legal concept in that area was strengthened with the emergence of the procedure of redemption of private property objects for public use (hereinafter - redemption for public use) in 
the national legislation, which was separated from the procedure of compulsory alienation, where a mandatory condition of the legality was the voluntary consent of the property owner to the expropriation and when the refusal could not automatically lead to the alienation of property on the basis of an administrative act. As a result the redemption relationship for public needs is automatically perceived by some scholars as private and legal, sometimes without any argument. For example, I. Ya. Holovnia similarly characterizes the redemption of land plots for public needs as transactions, and the relationships that are formed - as civil ones (Holovnia I. Ya., 2015) (although we should note that the scholar calls the procedure of forced alienation as "completely public and legal" (Holovnia I. Ya., 2015)).

However, the justification, which is based only on the fact of the application of a civil contract and is not supported by anything else, is rather weak, in our opinion. In particular, it seems erroneous to ignore the provisions of the current regulatory acts, the analysis of which indicates that the relationship of redemption for public needs and the relationships of sales are not identical and have too many differences, the combination of which suggests that they are independent (one from another) legal relations. Besides, the expediency of further use of civil contracts to address redemption issues for public needs within legal realities, when there is a wider range of legal instruments of public administration entities' activities, which is more consistent with the nature of expropriation relationships.

In this regard, we consider it necessary to revise the existing approach to the regulation of the redemption procedure for public needs and bring it in line with modern European practice. Therefore, the purpose of the article is to continue the discussion on the correlation between the expropriation relationships (for the purposes of the article it will be mainly about redemption for public needs, because the procedure of forced alienation is not identified with sales by modern scholars) and sales expanding the arguments in favor of the inexpediency of their identification and further determining the need to abandon the use of civil agreements within the expropriation procedure. To achieve the purpose, it is necessary to perform the following tasks: to get acquainted with the arguments of scholars put forward to support and criticize the idea of forced sales in the pre-revolutionary period; to consider the approaches of modern scholars to the distinction between expropriation and sales relationships; to establish differences between the institutions of sales and expropriation, which were not identified by other scholars; to formulate conclusions.

The research methodology consists of general and special methods of scientific cognition, including historical and legal, comparative and legal, systematic and structural methods, deduction, induction, analysis, synthesis, etc. The historical and legal method allowed to find out the peculiarities of understanding the legal phenomenon of the expropriation in the pre-revolutionary period, to establish the preconditions for the use of civil agreements within the expropriation procedure. The comparative and legal method was used to compare regulatory 
provisions, scientific approaches, legal institutions of sales and expropriation. Due to the systematic and structural method the author has studied the issue of urgency and expediency of the application of the idea of forced sales in regard to the modern institution of expropriation, taking into account the provisions of regulatory acts, achievements of domestic scholars, and also taking into account separate specific features of using contracts within the expropriation procedure. Methods of deduction, induction, analysis and synthesis were used to study the provisions of regulatory acts and scientific papers, studying the characteristics and certain aspects of relations, procedures and purchase and sale agreements, as well as expropriation agreements, making intermediate and general conclusions, formulating propositions and recommendations, areas of further research.

\section{Expropriation as sales in the pre-revolutionary period}

Starting to study the outlined issues, we would like to note that scholars in the pre-revolutionary period already criticized the idea of forced sales, which, however, was not accepted by its supporters under any circumstances. For example, M. V. Venetsianov, referring to the works of foreign scholars (Venetsianov, 1891), noted that the theory of the contractual nature of expropriation, in the opinion of supporters of that approach, was not hindered by the fact that there was no will of the seller under the forced alienation, which was replaced or supplemented by the court decisions, since the coercion of alienation did not violate the effect of the contract and it was not the issue on actual violation of the freedom of will (Venetsianov, 1891). That position has surely led to misunderstandings with other scholars, who emphasized the importance and inalienability of the parties' consent for the sales relationships (Venetsianov, 1891; Vas'kovskij, 1896). That approach has also been criticized for the various consequences of the purchase and sale agreement and expropriation agreement, as well as the rights, obligations and responsibilities of their parties (Venetsianov, 1891; Vas'kovskij, 1896). But that argument was also considered insignificant, because they considered significant only those features of expropriation that coincided with the features of sales - the sale of a certain individual property value at the usual price, exchange of property and the price (Venetsianov, 1891). Although the formation of the price of agreement within the expropriation and sales relations differed significantly (Venetsianov, 1891), it did not affect the greatness of the private and legal (contractual) concept of understanding the expropriation.

Hence, we see that no arguments against such a position, no matter how strong they were, had no relevance to the representatives of the private and legal concept, because they simply ignored them, guided only by the fact of using the purchase and sale agreement (or purchase contract). In other words, it follows from the above that in cases where the case contained the name of the purchase and sale agreement (or purchase contract, or other documents that mediated the trade) and the fact of payment for the alienated property, it was enough for that category of jurists to be convinced according to the civil nature of the relations related to that case, in general. 
Such approach, in some ways, can be justified by several circumstances that took place during the pre-revolutionary times and were, in our opinion, prerequisites for the use of civil contracts within the expropriation procedure, namely: 1) the subject matter of administrative (police) law was limited to public administration issues, but administrative and legal relations were exclusively related to the executive (administrative) and coercive (overcoming resistance) activities (Tarasov, 1910); 2) public administration had narrow instruments at its disposal, which were limited to administrative rulings, prescriptions and orders (Tarasov, 1910); 3) the institution of administrative agreement had not been developed and implemented into the practice of public administration, which used only the above-mentioned unilateral acts of public administration; 4) the science of administrative law was at an early stage of development (Antonenko, 2019), and therefore it was too early to talk about expanding the subject matter of administrative law, the subject composition and types of administrative and legal relations, instruments of public administration, etc., which would allowed to look at the expropriation procedure just from the point of view of administrative law.

The above allows us to conclude that there were no necessary conditions for settling the issues of redemption without the assistance of private and legal instruments in the pre-revolutionary times. However, the situation has changed radically now. Moreover, the state of public administration, normative and legal regulation and scientific research in the country indicates, in our opinion, that the need to use civil contracts for expropriation purposes has disappeared, since it is possible to replace them with an alternative administrative agreement. It is evidenced by the European experience in regulating the expropriation (which we will not study within this article) and the results of legal analysis of regulatory acts and scientific sources, which clearly indicate the many differences between the relationships of sales and redemption, and hence the inconsistency of instruments provided by the legislation to the purpose and essence of the expropriation. We offer to get acquainted with them in details in order to demonstrate this.

\section{Delimitation of expropriation and sales}

Within the outlined purposes, we primary consider it appropriate to recall the thorough study of Ye. P. Suietnov (Suietnov Ye. P., 2013), who, based on the study of current legislation, paid attention to a number of major differences between private and legal agreements and redemption agreements for public needs. It follows from his analysis that the outlined legal constructions should be distinguished from each other, based on the following circumstances:

1) expropriation is an independent reason for the acquisition (into municipal and state ownership) and termination of the ownership right of land plots, which is separated from the reason related to the conclusion of civil contracts and / or the decision of the owner of the land plot (Suietnov Ye. P., 2013), according to the Articles 83-84, 140 of the Land Code (hereinafter - the LC) of Ukraine (Land Code of Ukraine, 2001); 
2) purchasers of expropriated property may not dispose of it at their own discretion, as it is in case with the acquisition of property rights under civil contracts, since they are limited in the use and disposal of property for expropriation purposes (Suietnov Ye. P., 2013), which is directly enshrined in Part 5 of the Art. 4 of the Law of Ukraine "On the alienation of land plots, other immovable property located on them, which are in private ownership, for public needs or for reasons of public necessity" (Law of Ukraine on alienation of land plots, other real estate objects located on them, which are in private ownership, for public needs or for reasons of public necessity, 2009) (hereinafter - "On alienation of land plots ..."). In turn, the use of expropriated property not for the purposes of expropriation (not for public needs) is the ground for the former owner of the property to go to court with a claim for invalidation or termination of the contract of redemption of the land plot and compensation for damages related to the redemption in accordance with Part 3 of the Art. 153 of the LC of Ukraine (Suietnov Ye. P., 2013). The stated above is not inherent in the civil and legal relations of sales, exchange, etc., since it is not consistent with the fundamental principles of civil law set out in Part 1 of the Art. 319 of the Civil Code (hereinafter - the CC) of Ukraine (Civil Code of Ukraine, 2003) according to which the owner owns, uses and disposes of the property at own discretion;

3) redemption of property for public needs and civil contracts have different legal consequences: while the acquisition of land plots under civil contracts this property retains all the established encumbrances and restrictions, such as servitudes (Part 2 of the Art. 110 of the LC of Ukraine, Part 6 of the Art. 403 of the CC of Ukraine), which is not typical for expropriation, after which all encumbrances and restrictions lose force, if they interfere with the use of property in accordance with its purposes (Suietnov Ye. P., 2013) (Part 2 of the Art. 18 of the Law of Ukraine "On alienation of land plots ...");

4) the formation of the redemption price within the expropriation and sales procedures is carried out according to different rules: only the stipulated value of the alienated property is paid in case of sales, but in case of expropriation the property owner is also reimbursed for damages caused to the owner in connection with the redemption, including the damages to the owner in regard to the early termination of obligations to third parties, in particular lost profits, in full force and effect (Suietnov Ye. P., 2013) (Part 1 of the Art. 5 of the Law of Ukraine "On alienation of land plots ...");

5) the moratorium on the alienation of land plots of state and municipal property for agricultural purposes, land plots of private property for commercial agricultural production and personal farming under the purchase and sale agreement does not apply to their alienation within the expropriation procedure (Suietnov Ye. P., 2013) (paragraphs "a", "b" of Part 15 of the Transitional Provisions of the LC of Ukraine);

6 ) in case of expropriation, the owner has the right to increase the size of the alienated property in accordance with Part 5 of the Art. 3 of the Law of Ukraine 
"On alienation of land plots ..." in cases that are impossible within civil sales procedure (Suietnov Ye. P., 2013);

7) expropriators (persons subject to expropriation (Suietnov Ye. P., 2014)) have the right to return the property alienated within the expropriation procedure, when the reasons for the latter are exhausted (i.e. the public need to use the expropriated property disappears), under the conditions specified in the Art. 19 of the Law of Ukraine "On alienation of land plots ...". According to the content of Parts 4-5 of the same Article, public authorities may alienate or transfer expropriated property for use only if the expropriator has notarized refusal to return it or does not notify about his desire to exercise the right to return it within six months. Obviously, such conditions for the return of property to the former owner and its subsequent sale are not inherent in the sales relationship (Suietnov Ye. P., 2013).

We consider it expedient to supplement the above stated with our own analysis of the differences between the relations of sales and redemption for public needs, which indicate against their identification. Thus, first of all, we would like to emphasize the differences between the nature of the needs and interests that are met through sales and expropriation, and the purpose of the origin of these relations. Sales relations arise in order to meet personal interests and needs, due to their private nature. Instead, the redemption relations for public needs, which already follows from their name and is confirmed by the provisions of the Articles 350-351 of the CC of Ukraine, the LC of Ukraine (the Art. 146 and other Articles, which mention the redemption for public needs), the Law of Ukraine "On alienation of land plots ...", arise solely to meet public or, in other words, public needs and, accordingly, the public interests. Satisfaction of personal (private) needs and interests through expropriation is illegal.

Secondly, the sales of real estate (as well as movable property) can be carried out under the general rules in any case, i.e. for any reason and at any time without any restrictions in this regard (except for those objects under the moratorium). In other words, the issue of property sales can be raised due to the desire to buy or sell real estate, to get money, to change the situation, place of residence, to get rid of unnecessary things, to meet any other personal needs. Instead, the redemption for public needs can be carried out only in cases established by law, namely - to meet public needs, an exhaustive list of which is enshrined in Part 1 of the Art. 7 of the Law of Ukraine "On alienation of land plots ...". The redemption for public needs for any other reason, is not allowed, as evidenced by the provisions of Part 2 of the Art. 2 of the Law of Ukraine "On alienation of land plots ...".

Thirdly, the CC of Ukraine provides a wide range list of objects that may be the subject of sales, including goods that will be created (purchased, acquired) by the seller in the future (Part 1 of the Art. 656 of the CC of Ukraine), property rights (Part 2 of the Art. 656 of the CC of Ukraine), the right of claim (Part 3 of the Art. 656 of the CC of Ukraine), currency values and securities (Part 4 of the Art. 656 of the CC of Ukraine), etc. Instead, the list of objects that 
can be expropriated in accordance with the current legislation is much narrower and includes only existing real estate existing at the time of expropriation: a land plot, house, other buildings, dwellings, perennials located on it (the Art. 350 of the CC of Ukraine, Part 1 of the Art. 3 of the Law of Ukraine "On alienation of land plots ...").

Fourth, we would like to pay attention to the fact that the expropriation relations and civil relations of sales (as well as exchange) also differ in terms of initiative and expression of will. In all cases of concluding civil contracts, the owner of the alienated property can and often initiates the agreement, since it is his interests and meets his personal needs. In cases of the expropriation, the initiative to expropriate property for public needs or for reasons of public necessity may belong only to executive authorities or local self-government agencies, special administrations for the management of territories and objects of nature reserves, persons who have received a special permit (license) for subsoil use, and enterprises engaged in construction, overhaul, reconstruction, operation of transport and energy infrastructure facilities, protective hydraulic structures and who have agreed the location of such facilities in cases and in the manner prescribed by the Art. 151 of the LC of Ukraine (Part 1 of the Art. 10 of the Law of Ukraine "On alienation of land plots ..."). The owner can only react positively (agree) or negatively (refuse) to the offer to buy his property for public needs, which usually have nothing to do with the personal interests and needs of the owner.

Fifth, we emphasize that most of the provisions of the CC of Ukraine on sales are not applicable to the expropriation relations, for example:

1) the provision on the possibility of acquiring the right to terminate the purchase and sale agreement unilaterally, enshrined in the Art. $658^{1}$ of the CC of Ukraine. The owner of the expropriated property cannot acquire the right to unilaterally terminate the redemption agreement (and this would make it impossible to meet public needs), but he has the right to go to court according to law only if the expropriated property is not used for expropriation purposes (Part 3 of the Art. 153 of the LC of Ukraine), as mentioned above;

2) provisions on quantity (the Art. 669 of the $\mathrm{CC}$ of Ukraine), quality (the Art. 673 of the CC of Ukraine), range (the Art. 671 of the CC of Ukraine), completeness (the Art. 682 of the CC of Ukraine) and set of goods (the Art. 683 of the CC of Ukraine), packaging (the Art. 685 of the CC of Ukraine), legal consequences and notification of the seller about the violation of contract conditions in their regard (the Articles 670,672, 678, 684, 686, 688 of the CC of Ukraine), verification of their compliance (the Art. 687 of the CC of Ukraine), confirmation of the goods compliance with the requirements of the legislation (the Art. 674 of the CC of Ukraine), guarantees of goods quality (the Art. 675 of the CC of Ukraine), warranty period (the Art. 676 of the CC of Ukraine) and the shelf life of the product (the Art. 677 of the CC of Ukraine), defects of the goods (the Art. 679 of the CC of Ukraine), terms of their detection and presentation of claims in 
this regard (the Art. 680 of the CC of Ukraine), statute of limitations applicable to such claims (the Art. 681 of the CC of Ukraine), legal consequences to recall the goods from the buyer (the Art. $681^{1}$ of the CC of Ukraine), sale of goods on credit (the Articles 694-695 of the CC of Ukraine), insurance of goods (the Art. 696 of the CC of Ukraine), etc. These norms do not extend their influence to the expropriation relations, at least for the reasons of inexpediency and inconsistency of the essence of the expropriation.

Similarly, not all general provisions of the CC of Ukraine on obligations may be applied to the expropriation relations, in contrast to private and legal relations, including sales relations. For example, the use of means of securing obligations, which include a penalty, surety, guarantee, pledge, retention, depositation, the right of trust property (the Articles $546-597^{13}$ of the CC of Ukraine) is not characteristic for the expropriation relations.

Regarding the legal consequences of violating the obligations, except cases of misuse of expropriated property (as noted above), they are not provided in regulatory acts, in contrast to private and legal obligations (the Article 610-625 of the CC of Ukraine). And even in this case, individuals can only file a lawsuit (Part 3 of the Art. 153 of the LC of Ukraine). The resolution of this issue out of court is not provided by law. In turn, from the analysis of the provisions of the Articles 610-625 of the CC of Ukraine and the Law of Ukraine "On alienation of land plots ..." there is no unambiguous answer as to whether it is possible to apply the Chapter 51 of the CC of Ukraine to the expropriation relations. In our opinion, since it is about the activity of public administration subjects, then legal consequences of the infringement of conditions of the redemption agreement should get a separate regulatory consolidation, since public authorities and local selfgovernment agencies, their officials unlike individuals can act only on the basis, within the powers and in the manner prescribed by the Constitution and laws of Ukraine (the Art. 19 of the Constitution of Ukraine (Constitution of Ukraine, 1996)). In addition, they do not act as subjects of civil law within the expropriation relations, since the expropriation procedure is carried out in order to perform public functions, tasks and powers, but not to meet their own needs. Accordingly, in the absence of indications on the consequences of breaking the terms of the redemption agreement, there are too many questions and doubts about how individuals can protect their rights: what norms to refer to, what to demand in claims, what results to expect, or in all cases of violations they have the right to demand termination of the redemption agreement, whether they can demand payment of penalties, etc. All this reduces the effectiveness of the observance and realization of the rights and freedoms of citizens, creates risks of their violation, contradicts the rule of law principle.

In such cases it is also unclear about the responsibility of the perpetrators. In our opinion, this issue needs a separate study, because breaking the terms of the redemption agreement not only violates the rights and interests of individuals, but also harms society, creates obstacles to meeting public needs, is the violation of public administration subjects' obligations and non-compliance with the principles 
of their activities. Therefore, the responsibility should be increased and should not be limited by civil and legal means.

Sixth, it should be noted that the purchase and sale agreement according to the current legislation is only one of the possible options for registration of the redemption for public needs. In particular, in accordance with Part 1 of the Art. 1, Parts 1-3 of the Art. 12 of the Law of Ukraine "On alienation of land plots ..." exchange contract and other transactions involving the transfer of the ownership right can be used for the specified purposes. Obviously, the relationship accompanied by the conclusion of other transactions cannot be sales relations.

Seventh, if we pay attention to the Articles 7-12 of the Law of Ukraine "On alienation of land plots ...", as well as the approaches of determining the structure of the expropriation procedure covered in the scientific literature, it can be seen that conclusion of a transaction for the redemption for public needs is only one of its stages. For example, D. V. Dudnyk specifies the following stages of the voluntary procedure of alienation of land plots for public needs: 1) approval of the location of the object; 2) initiation of the alienation of a land plot for public needs; 3) making a decision on the purchase of a land plot; 4) notification of the owner of a land plot on the decision on its redemption for public needs; 5) obtaining the consent of the owner of a land plot to conduct negotiations on the redemption; 6) conducting negotiations with the owner (owners) of a land plot; 7) concluding an agreement on the transfer of the ownership right for a land plot; 8) state registration of the ownership right (Dudnyk, 2015).

Accordingly, the redemption agreement, even in the form of the purchase and sale agreement will be only one of many elements of the expropriation. In this case, it is not clear why it is possible to make conclusions about all relations in general on the basis of only one of their elements?! Moreover, apart from concluding the purchase and sale agreement (exchange or other transaction), the other stages and components of the expropriation procedure (including its variant - the redemption procedure), which relate to the direct activities of the public administration and its exercise of public authoritative powers, are purely administrative and legal stages (in particular, the determination of public needs, consideration of propositions of authorized entities, approval of the location of the object, decision-making and issuance of an administrative act on the redemption, notification of the property owner about the taken decision, as well as state registration of the ownership right).

\section{Conclusions}

Thus, the analysis conducted in the article demonstrates that the relationships of redemption forpublicneedsarenottherelationshipsof sales, and cannotberecognized as civil on the grounds that the expropriation procedure involves the conclusion of the purchase and sale agreement. Moreover, the aggregate of differences between the relations of expropriation and sales suggests the persuasiveness and accuracy of the opinions of pre-revolutionary scholars (primarily of D. I. Mejer) that the purchase and sale agreement within the expropriation procedure is the one only in form and not in consequences (Mejer, 1902). 
This, in turn, raises the question of whether it is appropriate to revise the legal provisions on redemption for public needs and the contract that is concluded in this regard. In particular, it should be noted that the legal instruments that logically mediate the civil and legal relations of sales - are not intended and should not be used in atypical situations. Especially, if the legislation provides the possibility of using administrative agreements that are consistent with the specifics of the expropriation and meet the requirements for public administration. Accordingly, the use of the purchase and sale agreement within the expropriation procedure should no longer be perceived as an argument in favor of its private and legal nature, but as a relic of the past, which should be disposed of in favor of modern and instruments more relevant to the essence of outlined relations.

In this regard, we should consider the possibility of introducing a new instrument for Ukraine - an expropriation agreement - into legal circulation, which can correct the shortcomings of the current legislation, in particular about the uncertainty and ambiguity of the form of the redemption agreement, inconsistency of the form and content (purpose, consequences), etc. Therefore, there is currently the need for further scientific research of indicated issues, taking into account international experience of normative and legal regulation of expropriation and the practice of using expropriation agreements for the stated purposes.

\section{Bibliography:}

1. Венеціанов М. Экспропріація съ точки зрьнія гражданскаго права. Казань : Типографія Императорскаго Университета, 1891. 114 с.

2. Головня І.Я. Відчуження земельних ділянок для суспільних потреб чи з мотивів суспільної необхідності як підстава припинення права власності на земельну ділянку : дис. ... канд. юрид. наук : спец. 12.00.03. Одеса, 2015. 230 с.

3. Васьковскій Е.В. Учебникъ гражданскаго права. Выпускъ II. Вещное право. С.-Петербургъ : Изданіе юридическаго книжного магазина Н.К. Мартынова, 1896. 188 с.

4. Тарасов И.Т. Лекціи по полицейскому (административному) праву. Томъ второй. Общая часть. Москва : Печатня А.И. Снегиревой, 1910. 264 с.

5. Антоненко А. Про причини відсутності адміністративно-правових досліджень проблематики з відчуження об'єктів приватної власності для суспільних потреб чи 3 мотивів суспільної необхідності. Право Украӥни. 2019. № 7. С. 247-263.

6. Суєтнов Є.П. Юридична природа угоди, що укладається під час викупу земельної ділянки та розміщеного на ній нерухомого майна для суспільних потреб. Науковий вісник Ужггородського національного університету (Серія Право). 2013. Вип. 23, ч. II, т. 2. С. 63-67.

7. Земельний кодекс України : Закон України від 25 жовтня 2001 р. № 2768-III. Відомості Верховної Ради Украӥни (ВВР). 2002. № 3-4. Ст. 27.

8. Про відчуження земельних ділянок, інших об'єктів нерухомого майна, що на них розміщені, які перебувають у приватній власності, для суспільних потреб чи з мотивів суспільної необхідності : Закон України від 17 листопада 2009 р. № 1559-VI. Відомості Верховної Ради України (ВВР). 2010. № 1. Ст. 2.

9. Цивільний кодекс України : Закон України від 16 січня 2003 р. № 435-IV. Biдомості Верховної Ради України (ВВР). 2003. №№ 40-44. Ст. 356. 
10. Суєтнов Є.П. Суб’ єктний склад правовідносин з відчуження земельних ділянок для суспільних потреб та з мотивів суспільної необхідності. Вісник Харківського університету імені В.Н. Каразіна. Серія «ПРАВО». 2014. № 1106, Вип. 17. С. 152-157.

11. Конституція України : Закон України від 28 червня 1996 р. № 254-к/96-ВР. Відомості Верховної Ради України (ВВР). 1996. № 30. Ст. 141.

12. Дудник Д.В. Відчуження земельних ділянок для суспільних потреб: цивільноправовий аспект : дис. ... канд. юрид. наук : спец. 12.00.03. Харків, 2015. 204 с.

13. Мейер Д.И. Русское гражданское право : чтенія Д. И. Мейера, изданныя по запискамъ слушателей подъ редакціею А.И. Вицына. Съ приложеніемъ очерка русскаго вексельнаго права, біографій и портретовъ Д.И. Мейера и А.И. Вицына и трехъ указателей. Изд. 8-е, съ испр. и доп. А.Х. Гольмстена. С.-Петербургъ : Типографія Д.В. Чичинадзе, 1902. 804 с.

\section{References:}

1. VenetsianovM.(1891). Jekspropriacija s tochkizrenija grazhdanskogo prava[Expropriation from the point of view of civil law]. Kazan : Tipografija Imperatorskogo Universiteta [in Russian].

2. Holovnia I. Ya. (2015). Vidchuzhennia zemelnykh dilianok dlia suspilnykh potreb chy z motyviv suspilnoi neobkhidnosti yak pidstava prypynennia prava vlasnosti na zemelnu dilianku [Alienation of land plots for public needs or reasons of public necessity as a ground for termination of ownership of a land plot]. (Candidate's thesis). Odessa [in Ukrainian].

3. Vas'kovskij, E. V. (1896). Uchebnik grazhdanskogo prava. Vypusk II. Veshhnoe pravo [Textbook of civil law. Volume II. Property law]. Sankt-Peterburg : Izdanie juridicheskogo knizhnogo magazina N. K. Martynova [in Russian].

4. Tarasov I. T. (1910). Lekcii po policejskomu (administrativnomu) pravu. Tom vtoroj. Obshhaja chast' [Lectures on police (administrative) law. Volume two. Common part]. Moscow: Pechatnja A. I. Snegirevoj [in Russian].

5. Antonenko, A. (2019). Pro prychyny vidsutnosti administratyvno-pravovykh doslidzhen problematyky z vidchuzhennia ob'iektiv pryvatnoi vlasnosti dlia suspilnykh potreb chy z motyviv suspilnoi neobkhidnosti [Why there are no administrative-law studies of the issue relating to private ownership alienation for the social needs and on the grounds of social necessity]. Pravo Ukrainy, No 7, pp. 247-263 [in Ukrainian].

6. Suietnov Ye. P. (2013). Iurydychna pryroda uhody, shcho ukladaietsia pid chas vykupu zemelnoi dilianky ta rozmishchenoho na nii nerukhomoho maina dlia suspilnykh potreb [The legal nature of the agreement which is concluded during the purchase of the land and immovable property located on it for public needs]. Naukovyi visnyk Uzhhorodskoho natsionalnoho universytetu (Seriia Pravo), No 23 (Pt. 2, Vol. 2), pp. 63-67 [in Ukrainian].

7. Land Code of Ukraine from October 25 2001, No 2768-III (2002). Vidomosti Verkhovnoi Rady Ukrainy (VVR), No 3-4, Art. 27 [in Ukrainian].

8. Law of Ukraine on alienation of land plots, other real estate objects located on them, which are in private ownership, for public needs or for reasons of public necessity from November 17 2009, No 1559-VI. (2010). Vidomosti Verkhovnoi Rady Ukrainy (VVR), No 1, Art. 2 [in Ukrainian].

9. Civil Code of Ukraine from January 16 2003, No 435-IV (2003). Vidomosti Verkhovnoi Rady Ukrainy (VVR), No 40-44, Art. 356 [in Ukrainian].

10. Suietnov Ye. P. (2014). Sub'iektnyi sklad pravovidnosyn z vidchuzhennia zemelnykh dilianok dlia suspilnykh potreb ta $\mathrm{z}$ motyviv suspilnoi neobkhidnosti [The subject structure of legal relations of the alienation of land plots for public needs or on public necessity motives]. Visnyk Kharkivskoho universytetu imeni V. N. Karazina (Seriia "PRAVO"), No 1106, Vol. 17, pp. 152-157 [in Ukrainian]. 


\title{
ОСОБЛИВЕ АДМІНІСТРАТИВНЕ ПРАВО
}

11. Constitution of Ukraine from June 28 1996, 254-к/96-BP (1996). Vidomosti Verkhovnoi Rady Ukrainy (VVR), No 30, Art. 141 [in Ukrainian].

12. Dudnyk D. V. (2015). Vidchuzhennia zemelnykh dilianok dlia suspilnykh potreb: tsyvilnopravovyi aspect [Alienation of land plots for public needs: civil law aspect]. (Doctor's thesis). Kharkiv [in Ukrainian].

13. Mejer D. I., Vicyn, A. I. (ed.). (1902). Russkoe grazhdanskoe pravo: chtenija, izdannye po zapiskam slushatelej. S prilozheniem ocherka russkogo veksel'nogo prava, biografij i portretov D. I. Mejera i A. I. Vicyna i treh ukazatelej [Russian civil law: readings published according to the notes of listeners. With the attachment of an outline of Russian bills of exchange, biographies and portraits of Mejer, D. I. and Vicyn, A. I. and three indexes] ( $8^{\text {th }}$ ed., with corr. and add. Gol'msten, A. H.). Sankt-Peterburg: Tipografija D. V. Chichinadze [in Russian].

\section{ПРОДОВЖЕННЯ ДИСКУСІЇ НА ТЕМУ СПІВВІДНОШЕННЯ ВІДНОСИН ЕКСПРОПРІАЦІї ТА КУПІВЛІ-ПРОДАЖУ}

\author{
Анастасія Антоненко, \\ аспірантка кафедри адміністративного права та процесу \\ Інституту права \\ Київського національного університету імені Тараса Шевченка \\ orcid.org/0000-0003-2421-7768 \\ AntonenkoA@mail.univ.kiev.ua
}

\begin{abstract}
Мета. Метою статті є продовження дискусї на тему співвідношення відносин експропріації (а саме викупу об’єктів приватної власності для суспільних потреб) та купівлі-продажу, розширення аргументації на користь недоиільності їх ототожнення та подальще визначення необхідності відмови від використання ичивільно-правових угод у прочедурі експропріаціï.

Методи. Методологію дослідження складають загальні та спеціальні методи наукового пізнання, включаючи історико-правовий, порівняльно-правовий, системно-структурний, дедукиї, індукиії, аналізу, синтезу та ін.

Результати. У першій частині статті автор коротко розглядає основні доводи вчених, які висувались у дореволючійний період для підтримки та критики ідеї визначення експропріації як примусової купівлі-продажу. Автор формулює передумови використання цивільно-правових угод у процедурі експропріації та приходить до думки, щяо в дореволючійні часи необхідні умови для урегулювання питань викупу для суспільних потреб без приватноправових інструментів були відсутні. Автор стверджує, щзо порівняно з дореволючійним періодом сьогодні стан публічного адміністрування, нормативноправового регулювання і наукових розробок у державі свідчать про можливість заміни у процедурі експропріації циивільно-правових угод на адміністративні договори.

У другій частині статті автор наводить перелік основних відмінностей між відносинами експропріації та купівлі-продажу, які висвітлюються у сучасній українській науковій літературі, та доповнюе його власним аналізом розбіжностей між ними. Автор встановлює, щз вони відрізняються за: характером потреб та інтересів, які задовольняються за рахунок купівлі-продажу і експропріаціi, $і$ метою виникнення иих відносин; причинами та передумовами їх виникнення; об 'єктами правовідносин; критерієм ініціативи та волевиявлення; нормативно-правовими засадами (до відносин експропріації
\end{abstract}


є не застосовною більшість положень ЦК України про купівлю-продаж, про зобов 'язання, порушення зобов'язань). Окремо автор наголошує на тому, що за чинним законодавством договір купівлі-продажу є лише одним із можливих варіантів оформлення викупу для суспільних потреб, а його укладення - тільки одним з етапів процедури експропріації.

Висновки. Проведений у статті аналіз свідчить про те, щуо відносини викупу для суспільних потреб не є відносинами купівлі-продажу, а також не можуть визнаватись цивільно-правовими на тій підставі, щчо процедура експропріачії передбачає укладення договору купівлі-продажу. Автор звертає увагу на те, щүо правові інструменти, які логічно опосередковують чивільно-правові відносини купівлі-продажу, - не призначені та не повинні використовуватись в нетипових для цього ситуачіях. Автор пропонує розглянути можливість введення у правовий обіг нового для Украйни інструменту - експропріаційного договору, яким буде виправлено недоліки чинного законодавства.

Ключові слова: експропріація, викуп для суспільних потреб, відчуження об' єктів приватної власності для суспільних потреб чи з мотивів суспільної необхідності, купівля-продаж, договір викупу для суспільних потреб, договір купівлі-продажу, експропріаційний договір, співвідношення, відмінності, правова природа. 